\title{
Efficient Irrigation for Optimum Fruit Quality and Yield in Apples
}

\author{
Esmaeil Fallahi ${ }^{1}$ \\ Parma Research and Extension Center, University of Idaho, 29603 U of I Lane, \\ Parma, ID 83660 \\ Denise Neilsen and Gerry $H$. Neilsen \\ Pacific Agri-Food Research Center, Agriculture and Agri-Food Canada, Summerland, \\ British Columbia, Canada \\ Bahar Fallahi and Bahman Shafii \\ Parma Research and Extension Center, University of Idaho, 29603 U of I Lane, \\ Parma, ID 83660
}

\begin{abstract}
Additional index words. crop evapotranspiration, deficit irrigation, Malus $\times$ domestica partial root zone drying, water budget
Abstract. Use of crop evapotranspiration (ETc), when a precise crop coefficient value (Kc) is used, provides a reliable tool (irrigation scheduling) for determination of water requirement. In this process, Kc should be modified by percentage of ground shade (GS) and tree canopy maturity (M). In an experiment in Idaho with ET-based irrigation scheduling, each tree with a full microjet sprinkler system received an average of $6461.7 \mathrm{~L}(994 \mathrm{~mm})$, whereas each one with a full drip system used $3996 \mathrm{~L}(614.1 \mathrm{~mm})$ of irrigation water. In general, deficit drip irrigation was shown to initially increase yield as a result of induction of stress and the production of a higher number of fruit spurs. However, production declined if the extreme water deficiency was repeatedly applied to the trees over several years. Using a microjet sprinkler system, a partial root zone drying regime reduced fruit size but slightly improved fruit color. Application of water at $65 \%$ full drip rate, applied on both sides of the tree row (DD), reduced fruit size. However, when the $65 \%$ of full drip rate was applied to only one of the alternating sides of the tree every other week (PRD), fruit size was larger than those with DD treatment.
\end{abstract}

Increased world population mandates a more efficient use of land and water resources for agriculture and indications are that water supply will not be sufficient to meet growing demands by 2025 (Postel, 1998). This has been illustrated for semiarid fruit-producing regions of western North America (Neilsen et al., 2006). However, merging a new orchard design with an efficient irrigation system can result in lower water consumption (Neilsen et al., 2008) while producing higher quality fruits (Behboudian and Mills, 1997; Behboudian et al., 2005; Naor, 2006; Neilsen et al., 2010).

Methods of irrigation affect water consumption, which is a critical issue in many parts of the world including the Pacific Northwest region of the United States. Irrigation methods and injection of nutrients, particularly nitrogen, through water (fertigation) also play major roles in apple fruit quality and production (Fallahi et al., 2001a; Neilsen et al., 2009).

Irrigation with a drip system uses less water than sprinkler irrigation (Proebsting, 1994). However, irrigation through sprinkler systems can improve the establishment and maintenance of orchard floor vegetation. Sprinklers also create a cooler environment in the orchards under fruit-growing conditions of

Received for publication 19 Jan. 2010. Accepted for publication $11 \mathrm{Feb} .2010$.

Part of a colloquium (The Efficient Use of Alternative Water and Traditional Irrigation Sources in Horticulture) presented 25 July 2009 at ASHS-2009, St. Louis, MO; sponsored by the Water Utilization and Management (WUM) Working Group.

${ }^{1}$ To whom reprint requests should be addressed; e-mail efallahi@uidaho.edu.
Washington and Idaho (personal information). Research has been conducted with orchard fertigation through drip systems in British Columbia (Neilsen et al., 1994; Yao et al., 2001) and Europe (Zydlik and Pacholak, 2001). However, although there has been some progress in understanding nutrient additions in microirrigation systems through fertigation (Chun et al., 2001; Fallahi et al., 2001b; Neilsen and Neilsen, 2006a, 2006b; Neilsen et al., 2004a, 2004b), information on the tree growth, yield, and fruit quality in new apple cultivars under various regimes of drip or microjet sprinkler irrigation systems in the Pacific Northwest is lacking.

\section{WATER USE STUDY AT THE UNIVERSITY OF IDAHO}

Experiment description and irrigation regimes. The experiment was established at the University of Idaho Pomology Orchards at the Parma Research and Extension Center during spring and summer of 2002. 'Autumn Rose Fuji' trees on RN 29 (Nic29) rootstock were planted at $1.52 \times 4.27-\mathrm{m}$ spacing $(1540$ trees/ha). The experimental design was a randomized complete block with five irrigation treatments and five replicates. Each block contained 10 trees per plot (i.e., per irrigation treatment). The experimental site had a semiarid climate with an annual precipitation of $\approx 297 \mathrm{~mm}$ and a sandy loam soil of $\mathrm{pH} \approx 7.3$. Cultural practices other than irrigation were similar to those recommended for commercial orchards in the Pacific Northwest (Washington State University, 2009).

Irrigation treatments during 2004 through 2007 were as follows: 1) full microjet sprinklers (FS). Trees with this microjet sprinkler system were irrigated at the full rate of ETc as described subsequently once a week during each growing season since 2002; 2) partial root-zone drying sprinklers (PRS). This system was similar to the full microjet sprinkler except that two microjet sprinklers were attached to two lateral polyethylene lines, each located either on the south $\left(180^{\circ}\right)$ or north side $\left(180^{\circ}\right)$ of the tree row. Applications alternated from side to side at every 2 weeks. At each irrigation time, trees in this treatment received $50 \%$ of the FS treatment; 3) full drip (FD). In this system, one drip line was installed in a $10-\mathrm{cm}$ trench (subsurface), $30 \mathrm{~cm}$ away from and parallel to the tree row at each of the north and south sides of the tree row. Trees in this system received $100 \%$ of ETc but adjusted for canopy development (GS). Therefore, in this treatment, liters of water applied per tree $=(\mathrm{ETc}$ in $\mathrm{mm} /$ percent drip efficiency factor) $\times 1.52 \times 4.27 \mathrm{~m}$ spacing $\times \%$ GS. Efficiency for this system was considered to be $100 \%$; 4) DD. The amount of water applied in this system was $65 \%$ of that applied to FD system; 5) PRD. At each biweekly irrigation cycle, trees were only irrigated by one of these drip lines, and in the next cycle, they were irrigated by the other line. In this way, partial root-zone drying was created in the trees. The amount of water applied through this system was $65 \%$ of FD.

Calculation of water requirement. At the beginning of each season (approximately midMay), the soil profile was watered to saturation in all irrigation systems. After the initial irrigation, water requirements were determined by calculating ETc (crop evapotranspiration) where $\mathrm{ETc}=\mathrm{ETr} \times \mathrm{Kc}$. In this equation, ETr (Penman-Monteith reference 
evapotranspiration) was calculated from the Agri-Met Parma Weather Station data (Allen et al., 1998) and Kc was the crop coefficient. Each year starting in 2002, the crop water use coefficient was calculated as: $\mathrm{Kc}=\mathrm{K}_{\mathrm{c}}$ base $+\% \mathrm{M} \times\left(\right.$ mature $\mathrm{K}_{\mathrm{c}}-\mathrm{K}_{\mathrm{c}}$ base $)$. Percent canopy maturity $(\% \mathrm{M})$ was a measurement of canopy size and was calculated as: $\% \mathrm{M}=$ $3.05+2.558 \times(\% \mathrm{GS})-0.016 \times(\% \mathrm{GS})^{2} . \mathrm{Kc}$ base was the base coefficient, calculated as the percentage area between the rows that was occupied by a cover crop. In our experiment, spacing between rows was $4.27 \mathrm{~m}$ and the herbicide strip extended $0.61 \mathrm{~m}$ on either side of the row. Thus, Kc base was [4.27 - $(0.61 \times$ $2)] / 4.27=0.71$. Percentage of GS was estimated as the area of orchard shaded by the tree canopy at different stages of growth. Ground shading reached $61.76 \%$ and tree maturity reached $100 \%$ on 1 Aug. 2005. Thus, Kc values for mature trees were used after 1 Aug. 2005. The value for mature Kc for each month was adopted from Proebsting (1994) for apples with cover crop, i.e., 0.71 in May, 0.96 in June, 1.04 in July and August, 1.0 in September, and 0.79 in October.

Fruit yield and quality attributes. Yield and fruit quality data were collected during 2004 through 2007. However, in this report, yield and fruit quality attributes for only 2004 (young trees) and 2007 (mature trees) are reported. Methods for yield and quality measurements were similar to those described by Fallahi et al. (2001a).

Results of water use study. Water use in all irrigation systems increased as trees matured (Tables 1 and 2). Trees used the highest amount of water in July and August in all years. Trees with FS treatment received a significantly greater volume of water than those with drip systems every year. Trees with a FS system received $72 \%$ and $56 \%$ more water than those with a FD system in 2003 (data not shown) and 2004, respectively (Table 1). These differences between FD and FS systems were consistent $(38 \%$ to 41\%) after 2005 (Tables 1 and 2) because the trees had reached the maximum ground shading $(\approx 67 \%)$ and full maturity after 1 Aug. 2005. On average, mature trees with a FS system received $6461 \mathrm{~L}$ of water per tree (994 mm), whereas those with a FD system received $3996 \mathrm{~L}$ of water per tree $(614 \mathrm{~mm})$ over the 2006 and 2007 seasons (Table 2). Each tree with PRS received more water than those with any type of drip systems in 2004 and more than DD and PRD after 2004 (Tables 1 and 2). Although the volume of water applied to the trees with DD or PRD was only $65 \%$ of that applied to the trees with FD system, no major water stress symptoms were observed in the trees with DD or PRD systems. The only visible symptom was that trees receiving less than full levels of either sprinkler or drip irrigations had slightly early leaf senescence in late October, perhaps as a result of increased stress and ethylene production in the trees with lower irrigation.

Leib et al. (2006) compared three microsprinkler irrigation systems in mature 'Fuji' trees. The soil water content in the conventional

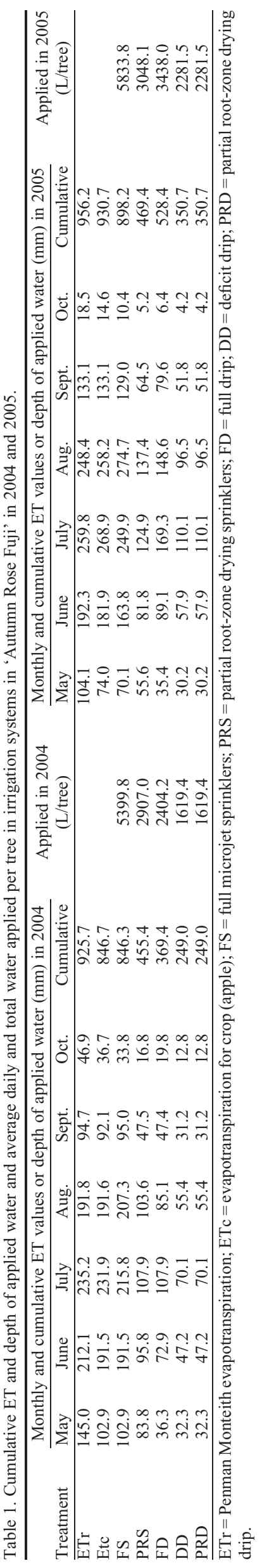


irrigation (CI) was maintained close to field capacity, which was only $60 \%$ to $70 \%$ of estimated ETc for apple without cover crop. In that study, deficit irrigation (DI) and PRS were at $\approx 50 \%$ to $60 \%$ of the CI. They found that the 3-year average potential evapotranspiration was $991 \mathrm{~mm}$ and irrigation amounts applied were $706 \mathrm{~mm}, 570 \mathrm{~mm}$, and $511 \mathrm{~mm}$ for CI, DI, and PRS irrigation regimes, respectively. We applied an average of $994 \mathrm{~mm}$ of water to our FS trees, which was $\approx 287 \mathrm{~mm}$ ( $\approx 29 \%$ ) higher than the levels applied to the CI treatment in the Leib et al. (2006) report. This difference is the result of average ETr being $\approx 116 \mathrm{~mm}$ higher in Idaho (Table 2) and FS being applied at full ETc level (Table 2), whereas CI trees in their experiment received water at $\approx 70 \%$ of ETc. Rainfall in both experiments was comparable.

\section{IRRIGATION EFFECTS ON YIELD AND FRUIT SIZE}

In our long-term experiment, 'Fuji' trees with FS and FD irrigation always had higher trunk cross-sectional area and canopy growth, whereas those receiving PRS were smaller than those with other treatments (data not shown). Trees with all drip systems tended to be more precocious and had higher yield per tree than trees with FS system when trees were young in 2004 (Table 3). Water stress resulted in a higher production of fruiting spurs in trees with all drip treatments, particularly those with DD or PRD (data not shown), leading to a higher production in 2004 (Table 3 ). However, yield per tree in DD treatment was significantly reduced as compared with trees grown with FS as trees matured, and the result for 2007 is shown in Table 3. In our study, FD is a preferred method of irrigation because it results in earlier and sustained production.

Leib et al. (2006) indicated that fruit size and yield of 'Fuji' apple in DI and PRS systems were similar to those of CI irrigation in the semiarid climate of Washington State. Lack of difference in their experiment is likely because the irrigation volume applied in their control or CI trees was only $60 \%$ to $70 \%$ of estimated ETc. Crop load can modify the effect of DI on fruit size in apple. Mpelasoka et al. (2001a) reported that 'Braeburn' apple trees with DI and CI irrigation treatments had similar yield in New Zealand. Naor et al. (2008) reported that yield and fruit size decreased as the rate of irrigation was reduced in 'Golden Delicious' apple in Israel.

\section{EFFECT OF IRRIGATION ON FRUIT QUALITY}

Fruit firmness. In our long-term study, fruit firmness at harvest was unaffected by various irrigation regimes in 2007 (Table 3). Previous reports indicate that low water applications may result in a reduction in apple firmness because of the advanced maturity in fruits with water stress (Drake et al., 1981; Mills et al., 1994). However, other researchers showed that apples from non-irrigated plots were firmer than those from irrigated plots (Assaf et al., 1975; Guelfat'Reich et al., 1974; Guelfat'Reich and Ben-Arie, 1979). Assaf et al. (1975) indicated that fruit from trees subjected to water deficit were smaller than those from CI trees, which may account for the observed increase in fruit firmness. Leib et al. (2006) observed that 'Fuji' apple fruits from trees with DI and PRS treatments were firmer than those from trees with CI treatment. Talluto et al. (2008) have shown that fruit firmness was unaffected by DI in 'Pink Lady' apple.

Fruit color. In our study, 'Autumn Rose Fuji' from trees receiving PRS treatment had slightly better (more uniform red) color than those from most other irrigation treatments (Table 3). Mills et al. (1994) reported that DI increased skin red color in 'Braeburn' apple. In contrast, DI did not affect fruit color in 'Pink Lady' in Australia (O'Connell and Goodwin, 2007; Talluto et al., 2008). The improved color development in apples with a DI system could be the result of the presence of less dense canopy and thus better light penetration (Lancaster, 1992) or could be the result of a reduced level of nitrogen $(\mathrm{N})$ in the leaves and fruits (Mills et al., 1994). Lower N in the leaf and fruit tissues has been shown to improve fruit color in 'Fuji' apple (Fallahi et al., 2001a).

Fruit soluble solids concentrations, starch degradation, and titratable acidity. In our study, trees receiving PRS treatment had significantly higher SSC than all other treatments when trees were young (in 2004), but trees with sprinkler systems had slightly lower soluble solids concentration (SSC) when trees were mature (in 2007) (Table 3). Other researchers reported that deficit irrigation increased SSC, including sucrose, glucose, fructose, and sorbitol in apple fruit, perhaps as a result of an increase in the concentration of dry matter (Kilili et al., 1996; Mills et al., 1994; Mpelasoka et al., 2000, 2001b; Naor, 2006). Leib et al. (2006) showed that SSC in fruits from trees receiving DI was higher than in fruits from trees receiving CI. A 2-year study by O'Connell and Goodwin (2007) on 'Pink Lady' in Victoria, Australia, showed that SSC tended to be higher in DI fruit than CI fruit for each of the 2 years. In contrast, Talluto et al. (2008) reported that 'Pink Lady' fruits from DI and CI treatments had similar SSC. Mills et al. (1994) and Marlow and Loescher (1984) reported that a high concentration of sorbitol will lead to the development of water core. Water core is not desirable in most apple cultivars, whereas it is considered as positive quality attributes for certain markets for 'Fuji'. In our experiment, 'Fuji' fruits from FD system always had higher water core (data not shown).

Factors that lead to a higher hydrolysis of fruit starch can result in higher SSCs (Kramer, 1983 ) in apple. However, a simple fruit dip in iodine solution (SDP) may not always be a reliable measure of the sugar concentration of fruit. For example in our study in 2004, fruit from trees receiving PRD treatment had a significantly higher SDP than those from FS irrigation regime, whereas fruits in both treatments had a similar level of SSC (Table 3 ). This could be the result of conversion of simple sugar to other metabolites.

Fruit sunburn. Tree with FS or FD systems had lower sunburn incidence than those with other treatments every year and data for 2004 and 2007 are shown in Table 3. Trees from these two treatments had larger canopies, more foliage, and thus protected the fruit against direct heat.

\section{CONCLUSIONS}

A significantly greater volume of water was applied to trees under FS than to those with drip systems. Application of water through a drip system, calculated based on full ETc rate and adjusted for groundcover, will always result in major water saving and often improved yield and fruit quality. Application of PRS reduces tree vigor and fruit weight, whereas it may improve fruit color and increase SDP. Fruit sunburn was reduced with application of water at full ETc rate in both FS and FD systems because trees under these irrigation systems had larger canopy and more foliage. With an increasing demand for newer cultivars, higher orchard density, and different canopy architecture, the impact of various irrigation systems and rates of water on fruit quality and yield of apples need to be studied in the future.

Table 3. Effects of different irrigation regimes on yield and fruit quality attributes of 'Autumn Rose Fuji' at harvest in young (in 2004) and mature (in 2007) trees.

\begin{tabular}{|c|c|c|c|c|c|c|c|c|c|c|c|c|c|c|}
\hline \multirow[b]{2}{*}{ Treatment } & \multicolumn{2}{|c|}{ Yield (kg/tree) } & \multicolumn{2}{|c|}{ Fruit wt $(\mathrm{g})$} & \multicolumn{2}{|c|}{ Fruit color } & \multicolumn{2}{|c|}{$\begin{array}{l}\text { Fruit soluble solids } \\
\left.\text { ( }{ }^{\circ} \text { Brix }\right)\end{array}$} & \multicolumn{2}{|c|}{$\begin{array}{c}\text { Fruit starch } \\
\text { degradation pattern }\end{array}$} & \multicolumn{2}{|c|}{$\begin{array}{l}\text { Fruit firmness } \\
\qquad(\mathrm{kg})\end{array}$} & \multicolumn{2}{|c|}{$\begin{array}{c}\text { Fruit sunburn } \\
(\%)\end{array}$} \\
\hline & $2004^{z}$ & 2007 & 2004 & 2007 & 2004 & 2007 & 2004 & 2007 & 2004 & 2007 & 2004 & 2007 & 2004 & 2007 \\
\hline FS & $5.3 \mathrm{~b}$ & $22.2 \mathrm{a}$ & $285.9 \mathrm{ab}$ & $303.2 \mathrm{a}$ & $3.5 \mathrm{a}$ & $3.6 \mathrm{a}$ & $15.3 \mathrm{~b}$ & $15.4 \mathrm{~b}$ & $3.3 \mathrm{~b}$ & $4.3 \mathrm{a}$ & $8.6 \mathrm{a}$ & $7.1 \mathrm{a}$ & $21.4 \mathrm{~b}$ & $10.0 \mathrm{~b}$ \\
\hline PRS & $8.9 \mathrm{ab}$ & $18.8 \mathrm{ab}$ & $235.5 \mathrm{c}$ & $254.0 \mathrm{~b}$ & $3.6 \mathrm{a}$ & $3.7 \mathrm{a}$ & $16.6 \mathrm{a}$ & $15.7 \mathrm{~b}$ & $3.5 \mathrm{ab}$ & $4.2 \mathrm{a}$ & $8.5 \mathrm{ab}$ & $7.3 \mathrm{a}$ & $42.0 \mathrm{a}$ & $12.9 \mathrm{ab}$ \\
\hline FD & $9.2 \mathrm{ab}$ & $20.3 \mathrm{ab}$ & $287.2 \mathrm{a}$ & $297.6 \mathrm{a}$ & $3.4 \mathrm{ab}$ & $3.8 \mathrm{a}$ & $15.1 \mathrm{~b}$ & $16.3 \mathrm{a}$ & $3.6 \mathrm{ab}$ & $4.0 \mathrm{a}$ & $8.4 \mathrm{ab}$ & $7.3 \mathrm{a}$ & $17.5 \mathrm{~b}$ & $12.3 \mathrm{ab}$ \\
\hline $\mathrm{DD}$ & $9.6 \mathrm{a}$ & $15.7 \mathrm{~b}$ & $270.1 \mathrm{~b}$ & $250.6 \mathrm{~b}$ & $3.0 \mathrm{~b}$ & $3.5 \mathrm{a}$ & $15.2 \mathrm{~b}$ & $15.8 \mathrm{ab}$ & $3.6 \mathrm{ab}$ & $4.3 \mathrm{a}$ & $8.4 \mathrm{ab}$ & $7.5 \mathrm{a}$ & $37.3 \mathrm{a}$ & $16.8 \mathrm{a}$ \\
\hline PRD & $11.0 \mathrm{a}$ & $17.9 \mathrm{ab}$ & $277.4 \mathrm{ab}$ & $284.0 \mathrm{a}$ & $3.6 \mathrm{a}$ & $3.5 \mathrm{a}$ & $15.0 \mathrm{~b}$ & $15.9 \mathrm{ab}$ & $3.8 \mathrm{a}$ & $4.3 \mathrm{a}$ & $8.2 \mathrm{~b}$ & $7.4 \mathrm{a}$ & $42.8 \mathrm{a}$ & $14.9 \mathrm{ab}$ \\
\hline
\end{tabular}

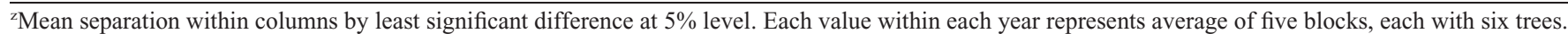
${ }^{\mathrm{y}}$ Fruit skin color rating: $1=$ green progressively to $5=$ uniform red. Starch degradation pattern: $1=$ least progressively to $6=$ highest.

$\mathrm{ETr}=$ Penman Monteith evapotranspiration; ETc = evapotranspiration for crop (apple); FS = full microjet sprinklers; PRS = partial root-zone drying sprinklers; $\mathrm{FD}=$ full drip; $\mathrm{DD}=$ deficit drip; $\mathrm{PRD}=$ partial root-zone drying drip. 
Overall, a drip system is recommended for modern apple orchards.

\section{Literature Cited}

Allen, R.G., L.S. Pereira, D. Raes, and M. Smith. 1998. Crop evapotranspiration. Guidelines for computing crop water requirements. FAO Irrigation and Drainage Paper 56. FAO, Rome, Italy.

Assaf, R., I. Levin, and B. Bravdo. 1975. Effect of irrigation regimes on trunk and fruit growth rates, quality and yield. J. Hort. Sci. 50:481493.

Behboudian, M.H. and T.M. Mills. 1997. Deficit irrigation in deciduous orchards. Hort. Rev. (Amer. Soc. Hort. Sci.) 21:105-131.

Behboudian, M.H., B.S. Mpelasoka, Z. Singh, and T.M. Mills. 2005. Quality responses of deciduous fruits to deficit irrigation, p. 33-43. In: Dris, R. (ed.). Fruits: Growth, nutrition, and quality. WFL Publisher (Science \& Technology), Helsinki, Finland.

Chun, I.J., E. Fallahi, W.M. Colt, B. Shafii, and R.R. Tripepi. 2001. Effects of rootstocks and microsprinkler fertigation on mineral concentrations, yield, and fruit color of 'BC-2 Fuji'. Apple. J. American Pomol. Soc. 55:197-205.

Drake, S.R., E.L. Proebsting, M.O. Mahan, and J.B. Thompson. 1981. Influence of trickle and sprinkle irrigation on 'Golden Delicious' apple quality. J. Amer. Soc. Hort. Sci. 106:255-258.

Fallahi, E., W.M. Colt, and B. Fallahi. 2001a. Optimum ranges of leaf nitrogen for yield, fruit quality, and photosynthesis in 'BC-2 Fuji'. Apple. J. Amer. Pomol. Soc. 55:68-75.

Fallahi, E., I.J. Chun, G.H. Neilsen, and W.M. Colt. $2001 \mathrm{~b}$. Effects of three rootstocks on photosynthesis, leaf mineral nutrition, and vegetative growth of 'BC-2 Fuji' apple trees. J. Plant Nutr. $24: 827-834$

Guelfat'Reich, S., R. Assaf, B.A. Bravdo, and I. Levin. 1974. The keeping quality of apples in storage as affected by different irrigation regimes. J. Hort. Sci. 49:217-225.

Guelfat'Reich, S. and R. Ben-Arie. 1979. Effect of irrigation on fruit quality at harvest and during storage. Proc. XV Int. Congr. Refrig., Brussels, Belgium. 3:423-427.

Kilili, A.W., M.H. Behboudian, and T.M. Mills. 1996. Composition and quality of 'Braeburn' apples under reduced irrigation. Sci. Hort. 67: $1-11$.

Kramer, P.J. 1983. Water relations of plants. Academic Press, New York, NY.
Lancaster, J.E. 1992. Regulation of skin color in apples. Crit. Rev. Plant Sci. 10:487-502.

Leib, B.G., H.W. Caspari, C.A. Redulla, P.K. Andrews, and J.J. Jabro. 2006. Partial root zone drying and deficit irrigation of 'Fuji' apples in a semi-arid climate. Irrig. Sci. 24:85-99.

Marlow, G.C. and W.H. Loescher. 1984. Water core. Hort. Rev. (Amer. Soc. Hort. Sci.) 6:189-251.

Mills, T.M., M.H. Behboudian, P.Y. Tan, and B.E. Clothier. 1994. Plant water status and fruit quality in 'Braeburn' apples. HortScience 29: 1274-1278.

Mpelasoka, B.S., M.H. Behboudian, J. Dixon, S.M. Neal, and H.W. Caspari. 2000. Improvement of fruit quality and storage potential of 'Braeburn' apple through deficit irrigation. J. Hortic. Sci. Biotechnol. 75:615-621.

Mpelasoka, B.S., M.H. Behboudian, and T.M. Mills. 2001a. Water relations, photosynthesis, growth, yield and fruit size of 'Braeburn' apple: Responses to deficit irrigation and to crop load. J. Hort. Sci. Biotechnol. 76:150-156.

Mpelasoka, B.S., M.H. Behboudian, and S. Ganesh. 2001b. Fruit quality attributes and their interrelationships of 'Braeburn' apple in response to deficit irrigation and to crop load. Gartenbauwissenschaft 66:247-253.

Naor, A. 2006. Irrigation scheduling and evaluation of tree water status in deciduous orchards. Hort. Rev. (Amer. Soc. Hort. Sci.) 32:111-165.

Naor, A., S. Naschitz, M. Peres, and Y. Gal. 2008. Responses of apple fruit size to tree water status and crop load. Tree Physiol. 28:1255-1261.

Neilsen, D., G.H. Neilsen, D. Gregory, T. Forge, and B.J. Zebarth. 2008. Drainage losses of water, $\mathrm{N}$ and $\mathrm{P}$ from micro-irrigation systems in a young, high density apple planting. Acta Hort. 792:483-490.

Neilsen, D., G.H. Neilsen, L. Herbert, and S. Guak. 2010. Effect of irrigation and crop load management on fruit nutrition and quality for Ambrosia/M.9 apple. Acta Hort. (in press).

Neilsen, D., S. Smith, G. Frank, W. Koch, Y. Alila, W. Merritt, B. Taylor, M. Barton, J. Hall, and S. Cohen. 2006. Potential impacts of climate change on water availability for crops in the Okanagan Basin, British Columbia. Can. J. Soil Sci. 86:909-924.

Neilsen, G.H. and D. Neilsen. 2006a. Response of high density apple orchards on course-textured soil to form of potassium applied by fertigation. Can. J. Soil Sci. 86:749-755.

Neilsen, G.H. and D. Neilsen. 2006b. The effect of K-fertilization on apple fruit $\mathrm{Ca}$ concentration and quality. Acta Hort. 721:177-184.
Neilsen, G.H., D. Neilsen, and L. Herbert. 2009. Nitrogen fertigation concentration and timing of application affect nitrogen nutrition, yield, firmness, and color of apples grown at high density. HortScience 44:14251431.

Neilsen, G.H., D. Neilsen, L.C. Herbert, and E.J. Hogue. 2004a. Response of apple to fertigation of $\mathrm{N}$ and $\mathrm{K}$ under conditions susceptible to the development of K deficiency. J. Amer. Soc. Hort. Sci. 129:26-31

Neilsen, G.H., D. Neilsen, E.J. Hogue, and L.C. Herbert. 2004b. Zinc and boron nutrition management in fertigated high density apple orchards. Can. J. Plant Sci. 84:823-828.

Neilsen, G.H., P. Parchomchuck, and D. Neilsen. 1994. Fertigation of fruit trees. The B.C. experience, p. 191-199. In: Peterson, A.B. and R.G. Stevens (eds.). Tree fruit nutrition. Good Fruit Growers, Yakima, WA.

O'Connell, M.G. and I. Goodwin. 2007. Responses of 'Pink Lady' apple to deficit irrigation and partial root zone drying: Physiology, growth, yield, and fruit quality. Aust. J. Agr. Res. 58: 1068-1076.

Postel, S. 1998. Water for food production: Will there be enough in 2025? Bioscience 48:629637.

Proebsting, E. 1994. Strategy development for managing drought, p. 39-50. In: Williams, K.M. and T.W. Ley (eds.). Tree fruit irrigation. Good Fruit Grower, Yakima, WA.

Talluto, G., V. Farina, G. Volpe, and R. Lo Bianco. 2008. Effects of partial root zone drying and rootstock vigor on growth and fruit quality of 'Pink Lady' apple trees in Mediterranean environments. Aust. J. Agr. Res. 59:785-794.

Washington State University. 2009. Washington State University Tree Fruit Research \& Extension Center. 4 July 2009. <http://www.tfrec. wsu.edu/ $>$.

Yao, S., G.H. Neilsen, and D. Neilsen. 2001. Effects of water stress on growth and mineral composition of 'Gala' apple fruit. Acta Hort. 564:449-456.

Zydlik, Z. and E. Pacholak. 2001. Fertigation effects on the concentration of mineral components in the soil and leaves, and the yield and quality of fruits in two apple tree cultivars, p. 457-463. In: Neilsen, D., E. Fallahi, G. Neilsen, and P. Peryea (eds.). Proc. of Fourth International Symposium on Mineral Nutrition of Deciduous Fruit Crops. Acta Horticulturae 564, International Society for Horticultural Science, Gent, Belgium. 